\title{
The influence of Exchange Rate and Freight Cost Toward Export Volume of Adidas at PT Apparel One Indonesia 1 Semarang
}

\author{
Adelia Regita Putri, Endang Sulistyani*, Paniya \\ International Business Management, State Polytechnic of Semarang, Indonesia
}

\begin{abstract}
ABSTRAC
Exports volume of Adidas from time to time is not stable because the amount always fluctuates and shows the decrease every year. This study aims to determine the effect of the exchange rate and freight cost partially and simultaneously on the export volume of Adidas at PT Apparel One Indonesia 1 and to find out how much all independent variables contribute to the dependent variable. The independent variables used in this study are the exchange rate and freight cost, while the dependent variable is the export volume of Adidas. This research uses an explanatory research type with a quantitative approach. The data used in this study is secondary data from literature reviews and observations, and comes from PT Apparel One Indonesia 1 with a time series from January 2014 to December 2019 and Bank Indonesia from January 2014 to December 2019. The output of this study shows that both variables affect export volume simultaneously. Meanwhile, partially, the exchange rate variable has a negative and significant effect on the export volume of Adidas. The freight cost variable has a negative and significant effect on the export volume of Adidas.
\end{abstract}

Key words: exchange rate, freight cost, export volume 


\title{
Pengaruh Nilai Tukar dan Ongkos Angkut terhadap Volume Ekspor Adidas pada PT PT Apparel One Indonesia 1 Semarang
}

\begin{abstract}
Abstrak
Volume ekspor Adidas dari waktu ke waktu tidak stabil karena jumlahnya selalu berfluktuasi dan menunjukkan penurunan setiap tahunnya. Penelitian ini bertujuan untuk mengetahui pengaruh nilai tukar dan biaya angkut secara parsial dan simultan terhadap volume ekspor Adidas pada PT Apparel One Indonesia 1 dan untuk mengetahui seberapa besar kontribusi semua variabel independen terhadap variabel dependen tersebut. Variabel bebas yang digunakan dalam penelitian ini adalah nilai tukar dan biaya angkut, sedangkan variabel terikatnya adalah volume ekspor Adidas. Penelitian ini menggunakan jenis penelitian eksplanatori dengan pendekatan kuantitatif. Data yang digunakan dalam penelitian ini adalah data sekunder dari tinjauan pustaka dan observasi, serta bersumber dari PT Apparel One Indonesia 1 dengan time series Januari 2014 hingga Desember 2019 dan Bank Indonesia Januari 2014 hingga Desember 2019. Output dari penelitian ini menunjukkan bahwa kedua variabel tersebut mempengaruhi volume ekspor secara bersamaan. Sedangkan secara parsial variabel nilai tukar berpengaruh negatif dan signifikan terhadap volume ekspor Adidas. Variabel biaya angkut berpengaruh negatif dan signifikan terhadap volume ekspor Adidas.
\end{abstract}

Kata kunci: nilai tukar, biaya pengiriman, volume ekspor 


\section{INTRODUCTION}

The development of the industry in this era of globalization is growing rapidly. Several sectors of the industry rely on international trade as the main activity in making profits. International trade is trading activity that involves more than one country. This happens because in certain companies, they sell all of their industrial products to other countries or by exporting them. Exports are selling goods abroad by using the payment system, quality, quantity and other terms of sales approved by the exporters and importers (Amir, 2007)

Garment manufacturing industry build its investment and production capacity mainly based on foreign markets and export. Based on data from the Ministry of Industry, garment has become the fourth biggest export commodities of Indonesia. One of the companies that focuses on the garment industry is PT Apparel One Indonesia 1. Established in 2011, PT Apparel One Indonesia 1 has the largest customer, Adidas International Trading. This company is a manufacturing company that produces various kinds of sportswear with different models or styles and materials. All the products are exported to many countries in European, Asian and America continent. The amount of Indonesia export in USD kept fluctuating from 2014 to 2018. Then, in 2019, there was a slight drop in from 7.322.500.000 USD to 7.072.500.000 USD. Besides, the export volume in ton descrease gradually from 2015 to 2019 .

Data from PT Apparel One Indonesia 1 showed and explained the total volume of all exported products of PT. Apparel One Indonesia 1. The amount of the export volume of Adidas at PT. Apparel One Indonesia 1 was 4.123 .112 pieces in $2014,5.211 .598$ in $2015,5.100 .720$ in $2016,4.860 .332$ pieces in 2017, 3.843.474 in 2018 and 3.860.911 pieces in 2019. We can conclude that the number of export fluctuate from year to year and decrease from 2016 until 2018. However, in 2019 the volume increased. As an export oriented company, PT. Apparel One Indonesia 1 must face up new challenges to come. Some factors affecting exports are exchange rate and freight cost. Exchange rate is an important factor in international trading as it is used as a guidelines in international payment. In carrying out export-import activities, PT Apparel One Indonesia 1 uses the USD (US Dollar) currency as a means of payment. Changes in the rupiah exchange rate against the US dollar have always been considered by the company.

Sasono (2013:186) stated that "international trade is influenced by the exchange rate. The exchange rate is a comparison of the purchasing power of each country's currency". According to Sukirno (2015:397) the exchange rate shows the price or value of a country's currency expressed in the value of another currency. It can also be defined as the amount of domestic money needed or the amount of Rupiah needed to obtain one unit of foreign currency. In a previous research, Edward and Hlatshwayo (2020) concluded that exchange rate has a significant and positive effect on export volume. On other hand, Cardebat, and Firguet (2019) stated that exchange rate has a significant negative impact on export volume. Meanwhile Gallego et al. (2019) stated that exchange rate non significant on export volume because exchange rate volatility does not seem to be a major factor in determining volumes of trade.

In export activity, the process of transferring the products it is necessary. In the process of transferring the product, costs are needed. Freight Cost is the amount of packing cost and shipping cost to transport goods from one place to another, whether by land, sea, or air. PT. Apparel One Indonesia 1 uses the services of logistic companies in carrying out export activities. The export transaction carried out certainly cannot be separated from type of incoterm used.

According to research conducted by Prasojo (2017) stated that the distribution costs have a significant and negative effect on 
the export volume of organic fertilizer PT. Indmira Yogyakarta. It means that the higher distribution cost, then the export volume will decrease. On other hand, Chi (2016) stated freight cost influences export volume. Meanwhile, Jiang et al (2018) concluded that freight cost not significant toward export volume.

Factors of exchange rates and freight costs can be used as company considerations when it will make improvements to the increase in export volume. The company needs to evaluate these factors in order to be able to increase its export volume every month. This makes the company need to know which factors have the greatest influence on the export volume so that when making policy, company management knows which factors should be prioritized for review. Given this background, in this research interested in analyzing The Influence of Exchange Rate and Freight Cost Toward Export Volume of Adidas at PT. Apparel One Indonesia 1.

\section{Exchange Rate}

Exchange rate is the value of a foreign currency compared to domestic currency (Sasono, 2015:186). Foreign trading is definitely more complex than domestic trading because of the currency difference between two countries. Sukirno (2015:397)) stated that exchange rate indicates the price or value of a country's currency expressed in the value of another country's currency. It can also be defined as the amount of domestic currency needed, or the amount of rupiah needed to obtain one unit of foreign currency.

Ratana et al (2012) stated that indonesia is used floating system for exchange rate. Where currency changes are in accordance with the economic conditions of a country. When the currency value of exporting country falls, then the price of goods will become cheaper for importers. This conditions brings more profit for exporters, because importers bought more in cheapest price.
Edwards and Hlatshwoyo (2020) conducted a research on the influence of exchange rate on export volume in South Africa. According to the analysis that has been done, the result of hypothesis test showed that exchange rate has a positive significant effect on export volume. A weaker exchange rate is expected to boost the value of exports while reducing the value of imports, thus improving the trade balance. According previous research by Mejaya (2016) exchange rate has negative and significant influence toward export volume. If IDR depreciates, the export volume will increase and vice versa.

\section{Freight Cost}

Jiang et al (2018) stated that "freight cost is the transaction price in freight transportation, while transportation cost is an important part of the total trade cost" Therefore, freight rate has become an important indicator for international trade enterprises to determine trade orders and select trade partners (Geetha and Uthayakumar, 2014).

According Sembiring and Sasono (2018) 1. The increase of US Dollar exchange rate towards IDR brings significant impact towards non-oil \& natural gas export with positive direction. Land transportation freight brings significant impact towards non-oil \& natural gas exportwith positive direction.

According to (Barua et al, 2020) international freight transportation pertains to the physical process of moving goods between countries by ship, air, rail, truck, pipeline or intermodal. International freight transportation can involve a multitude of stakeholders including one or multiple shippers, carriers, forwarders, third-party logistics services, and customs of two or more countries for each movement. Compared to domestic goods movement, international freight transportation is characterized by large volume. 


\section{Theoretical Framework}

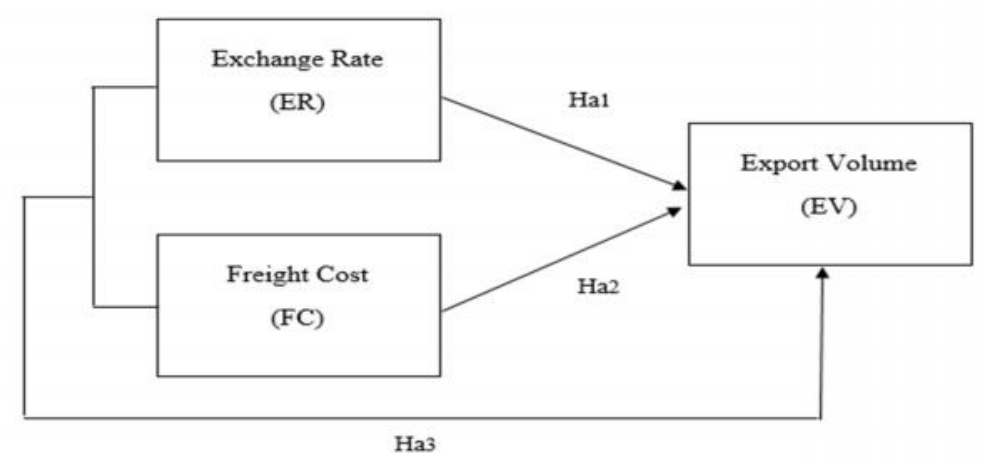

Source: Sembiring and Sasono (2018) developed in research (2020)

\section{Research Hypothesis}

Ha1 : Exchange rate influences export volume.

Ha2 : Freight cost influences export volume. Ha3 : Exchange rate and freight cost influences export volume.

\section{METHOD}

This research applied explanatory research method with quantitative approach. This analysis method is used in order to solve as well as answer the problems being studied. While quantitative research method can be explained as a research method that statistically analyzes quantitative data to test the established hypothesis (Sugiyono, 2016: $8)$.

The data in this research were the secondary data from PT Apparel One Indonesia 1 and Bank Indonesia in January 2014-December 2019. The data collected by observation, interview, and documentary research. In this research, there are two independent variables which are Exchange Rate (ER) and Freight Cost (FC). The dependent variable in this research is Export Volume (EV).

The data are processed using IBM SPSS 25. There were several steps, firstly descriptive statistic. Descriptive statistic is a way of analyzing data as they are by describing and depicting all the gathered data (Sugiyono, 2016: 147). The approach used in this analysis is by presenting and describing data with table, graphic, or diagram.

Secondly, classic assumption test. Classic assumption test is used to find out whether there is a deviation in the data or not. There are five classic assumptions test instruments. There are multicollinearity, autocorellation, heteroscedasticity, normality, and linearity.

The third are F-Test and T-Test, F-test aims to examine whether all independent variables entered into the model are simultaneously influencing the dependent variable (Ghozali, 2018: 98). T-test aims to measure the influence of one independent variable in individually explaining the variation of dependent variable (Ghozali, 2018: 99).

Then, coefficient determination test aims to measure how far is the ability of a model in explaining the variation of dependent variable within the value of zero and one (Ghozali, 2018: 97). Multiple linear regression analysis in which the result is a regression model, can be used to predicts the value of the dependent variable according to the independent variables value changes (Sugiyono, 2017: 188). This statistical tool is used to find out the influence of several variables on one variable. 


\section{RESULTS AND DISCUSSION Descriptive Statistics}

The result of descriptive analysis that out of $72 \mathrm{~N}$ data. The independent variable in this research, exchange rate (ER) has highest value in March 2014 at 0,0000657 and the lowest value in October 2018 at 0,0000877 from $72 \mathrm{~N}$ data which then averaged at 13.411,33 Rupiah/USD with a standard deviation 857,117. Meanwhile the lowest value of the other independent variable, freight cost is 41,890 USD in December 2014 and the highest value is 81,975 Rupiahs/USD in August 2019. The average out of $72 \mathrm{~N}$ data is 65056,35 Rupiahs/ USD with a standard deviation of 10478,669 .
The result of descriptive statistics analysis on dependent variable explained that the the mean value of the dependent variable in this research (EV) is 375002,042 PCS with the lowest value (minimum) at 214.964 PCS in December 2018 and reaches 534.750 PCS as the highest value (maximum) in January 2017, as for the standard deviation of this variable is 74949,2154 . The low standard deviation value indicated that the distribution of export volume data is normal as it is not higher than the mean value.

\section{Classic Assumption Test}

Normality test tests carried out using onesample Kolmogorov-Smirnov statistical test.

Table 1 Normality Test

\begin{tabular}{|c|c|}
\hline \multicolumn{2}{|c|}{ One-Sample Kolmogorov-Smirnov Test } \\
\hline & $\begin{array}{c}\text { Unstandardized } \\
\text { Residual }\end{array}$ \\
\hline $\mathrm{N}$ & 72 \\
\hline Asymp. Sig. (2-tailed) &, $200^{\mathrm{c}}$ \\
\hline
\end{tabular}

Source: Data Processing Output IBM SPSS Statistics 25 (2020)

Table 1 shows that the significance value is 0,200 which is greater than the alpha of $0,05(0,200>0,05)$. It can be concluded that the data are normally distributed because the sig. value is 0,200 higher than 0.05.Therefore, the data in this research are normally distributed according to the graphic and statistic test results.
According to Ghozali (2018: 107) multicollinearity test aims to test whether the regression model found a correlation between independent variables. In a good regression model there should be no correlation between the independent variables.

Table 2 Multicollinearity Test

\begin{tabular}{|c|c|c|c|}
\hline \multicolumn{4}{|c|}{ Coefficient } \\
\hline \multicolumn{2}{|r|}{ Model } & \multicolumn{2}{|c|}{ Collinearity } \\
\hline & & Tolerance & VIF \\
\hline \multirow[t]{3}{*}{1} & (Constant) & & \\
\hline & Exchange Rate & ,707 & 1,414 \\
\hline & Freight Cost & ,707 & 1,414 \\
\hline \multicolumn{4}{|c|}{ a. Dependent Variable: Export volume } \\
\hline
\end{tabular}

Source: Data Processing Output IBM SPSS Statistics 25 (2020) 
From the table 2, the variance inflation factor (VIF) value of both independent variables are 1,414 which is less than 10 . Therefore, it can be concluded that there is no presence of multicollinearity among independent variables and each variable is feasible to use in the regression model.

According to Ghozali (2018: 137), the purpose of heteroscedasticity test is to test whether there is a variance inequality of residual between one observation to another.

\section{Table 3 Heteroscedasticity Test}

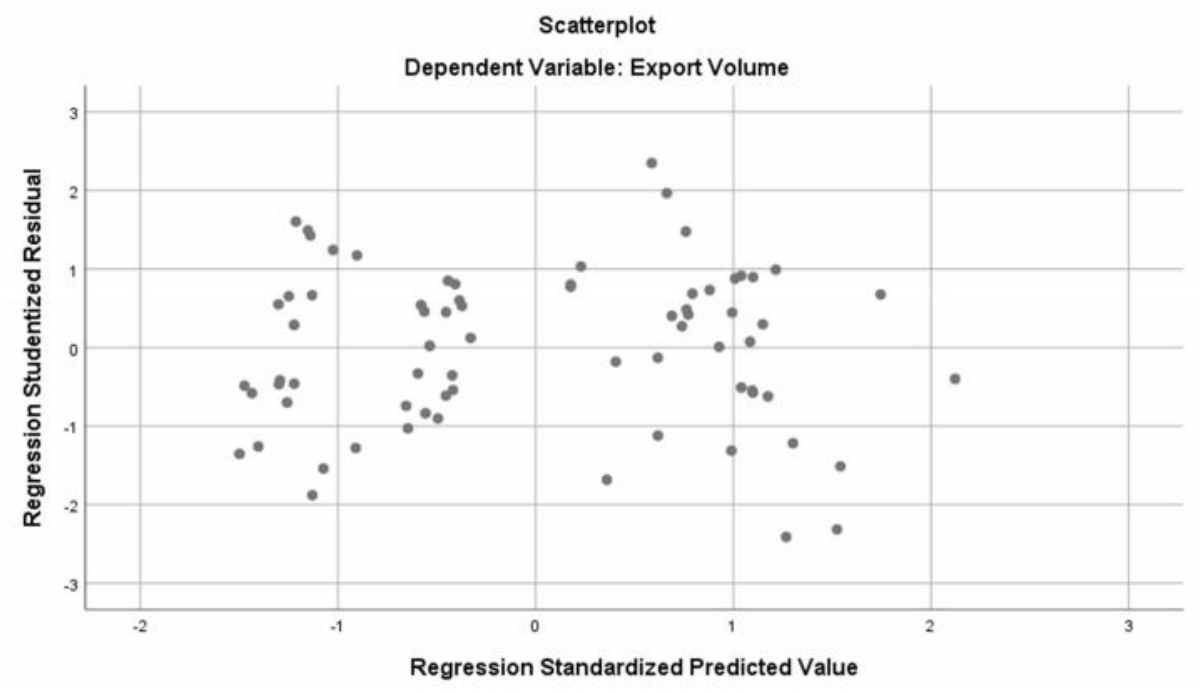

Source: Data Processing Output IBM SPSS Statistics 25 (2020)

Table 3 shows that it can be seen that the the points distribution doesn't form a certain tidy pattern (wavy, widened, and narrowed). Data distribution points are scattered randomly and spread above and below the zero (0) on the Y axis. So, it can be concluded that heteroscedasticity did not occur in this analysis which means that the regression model is fit to be used. In other words, this model is homoscedasticity.
According to Ghozali (2018:111), The autocorrelation test aims to test whether in the regression model there is a correlation between confounding errors in the period $t$ and the previous period. A good regression model is a regression that is free from autocorrelation. Durbin-Watson test were used in this research.

Table 4 Autocorrelation Test

\begin{tabular}{|c|c|}
\hline \multicolumn{1}{|c|}{ Model Summary } \\
\hline Model & Durbin-Watson \\
\hline 1 & 1,856 \\
\hline a. Predictors: (Constant), Exchange Rate, Freight Cost \\
\hline b. Dependent Variable: Export volume \\
\hline
\end{tabular}

Source: Data Processing Output IBM SPSS Statistics 25 (2020)

The table 4 shows that the autocorrelation test resulted that the Durbin Watson value (d) is 1,856 . The DW value of 1,856 will be compared with the Durbin Watson table using 
a significance value of $5 \%$. The number of independent variables is $2(\mathrm{k}=2)$ and the number of samples is $72(\mathrm{n})$, then the following values $\mathrm{DL}=1,5611$ and $\mathrm{dU}=$ 1,6751 are obtained.

Furthermore, the Durbin-Watson value of 1,856 is between the upper limit of $\mathrm{dU}$ $(1,6751)$ and $4-\mathrm{dU}(4-1,6751=2,3249)$. Therefore, the result of the autocorrelation test is $1,6751<1,856<2,3249$ (dU $<\mathrm{d}$
$<4-\mathrm{dU})$ and can be concluded that there is no autocorrelation in the regression model of this research.

According to Ghozali (2018: 167), the purpose of linearity test is to test whether the used model specification is correct or not. A linear model is the right model to test the variables. Linearity test can be done using Lagrange Multiplier.

Table 5 Linearity Test

\begin{tabular}{|c|c|}
\hline \multicolumn{2}{|c|}{ Model } \\
\hline Model & R square \\
\hline 1 &, 460 \\
\hline a. Predictors: (Constant), Exchange Rate, Freight Cost \\
\hline b. Dependent Variable: Export Volume \\
\hline
\end{tabular}

Source: Data Processing Output IBM SPSS Statistics 25, 2020

In table 5 , the results shows that the $\mathrm{R}^{2}$ value is 0,460 with the amount of data $\mathrm{N}=$ $72, \mathrm{C}^{2}$ value $=72 \times 0,460=33,12$. The $\mathrm{C}^{2}$ value then compared to the $\mathrm{C}^{2}$ table of 90,53 that obtained from df $=72-2=70$, and significance level of 0,05 . The result of this test is that $\mathrm{C}^{2}$ value is lower than $\mathrm{C}^{2}$ table $(33,12<90,53)$. Therefore, the model in this research is linear.

\section{Multiple Linear Regression}

The analytical method used in this study is multiple linear regression analysis using statistical test tools IBM SPSS 25.0. The variables studied are Exchange Rate and Freight Cost as independent variables and Export Volume as the dependent variable.

Table 6 Correlation Coefficients

\begin{tabular}{|l|c|}
\hline \multicolumn{2}{|c|}{ Model Summary } \\
\hline Model & $\mathrm{R}$ \\
\hline 1 &, $679^{\mathrm{a}}$ \\
\hline a. Predictors: (Constant), Exchange Rate, Freight Cost \\
\hline b. Dependent Variable: Export volume \\
\hline
\end{tabular}

Source: Data Processing Output IBM SPSS Statistics 25, 2020

From the table 6, it can be seen from the $R$ value which is the correlation between the flow of exchange rate and freight cost together which has a relationship to the Adidas export volume of 0,679. The interpretation of the relationship of independent variables together to export volume variables is strong.

The coefficient of determination is used to measure the ability of the model to explain 
the variation of the dependent (Ghozali 2018:97). The coefficient of determination to be used is adjusted $\mathrm{R}^{2}$ because the number of independent variables is more than 1 .

Table 7 Coefficient Of Determination

\begin{tabular}{|l|c|}
\hline \multicolumn{2}{|c|}{ Model Summary } \\
\hline \multicolumn{2}{|c|}{ Model } \\
\hline 1 & Adjusted R square \\
\hline a. Predictors: (Constant), Exchange Rate, Freight Cost \\
\hline b. Dependent Variable: Export volume \\
\hline
\end{tabular}

Source: Data Processing Output IBM SPSS Statistics 25, 2020

In table 7 , the value of the adjusted $\mathrm{R}^{2}$ is 0,445 or $44,5 \%$. Furthermore, it can be determined that the independent variables in this research which are exchange rate (ER) and freight cost (FC) are able to explain the changes of export volume (EV) for $44,5 \%$. While the rest percentage of $55,5 \%$ is explained by other variables outside the analyzed regression model.
F-test aims to examine whether all independent variables entered into the model are simultaneously influencing the dependent variable (Ghozali, 2018: 98). F test examines the effect of variable exchange rate (ER) and freight cost (FC) simultaneously on export volume $(\mathrm{EV})$.

Table 8 F-Test

\begin{tabular}{|c|c|c|c|}
\hline \multicolumn{4}{|c|}{ ANOVA $^{a}$} \\
\hline \multicolumn{2}{|r|}{ Model } & $\mathrm{F}$ & Sig. \\
\hline \multirow[t]{3}{*}{1} & Regression & 29,434 &, $000^{\mathrm{b}}$ \\
\hline & Residual & & \\
\hline & Total & & \\
\hline \multicolumn{4}{|c|}{ a. Dependent Variable: Export volume } \\
\hline
\end{tabular}

Source: Data Processing Output IBM SPSS Statistics 25, 2020

Based on the table 8, it can be explained that significance value is 0,000 or less than 0,05 which can be determined that $\mathrm{H} 03$ is rejected and $\mathrm{Ha} 3$ is accepted. Therefore, the F-test result showed that both variables of exchange rate (ER) and freight cost (FC) significantly influenced on export volume of Adidas. So it can concluded that exchange rate and freight cost simultaneously influences export volume.

T-test aims to measure the influence of one independent variable in individually explaining the variation of dependent variable (Ghozali, 2018: 99). T-test examines the partial influence of independent variable toward dependent variable. 
Table 9 T-Test

\begin{tabular}{|c|c|c|c|c|}
\hline \multicolumn{4}{|c|}{ Coefficients $^{\text {a }}$} \\
\cline { 3 - 5 } & Model & Standardized & \multirow{2}{*}{ B } & Sig. \\
\hline \multirow{2}{*}{1} & Exchange Rate & $-0,271$ & $-2,572$ & 0,012 \\
\hline \multirow{2}{*}{ Freight Cost } & $-0,786$ & $-7,470$ & 0,000 \\
\hline \multicolumn{2}{|c|}{ a. Dependent Variable: Export volume } \\
\hline
\end{tabular}

1. Exchange Rate toward Export volume of Adidas

Based on Table 9, it can be concluded that a sig. value of exchange rate variable is 0,012 which is less than than 0,05 . As a result, $\mathrm{H} 01$ is rejected and $\mathrm{Ha} 1$ is accepted. It means Exchange Rate (ER) partially and significantly influenced Export volume (EV).

2. Freight Cost toward Export volume of Adidas

According to Table 9, it is found that the value of significance for freight cost variable is 0,000 which is less than 0,05 . The conclusion is $\mathrm{H} 02$ is rejected and $\mathrm{Ha} 2$ is accepted, so that Freight Cost (FC) partially and significantly influenced Export volume (EV).

Based on the multiple regression analysis conducted in IBM SPSS Statistics 25 . The results can be seen in Table 20, the multiple regression equation model obtained is

\section{$\mathrm{EV}=\mathbf{- 0 , 2 7 1} \mathrm{ER}-\mathbf{0 , 8 7 6} \mathrm{FC}$}

From the result it can be concluded the effect of each variable toward export volume. Exchange rate has negative effect, and freight cost also has negative effect toward export volume. From the model regression the constant value indicates that the regression coefficient obtained from the exchange rate (ER) is-0,271. This means that an increase in the exchange rate of 1 USD will be followed by an decrease in export volume of 0,271 PCS assuming other variables are fixed.

On the other hand, the regression coefficient of the other independent variable of freight cost (FC) is $-0,876$ which means that every time there is an increase in freight cost of 1 USD, it will reduce export volume by 0,876 pcs and vice versa. So, the variable freight cost has a negative effect toward export volume.

\section{CONCLUSION}

The conclusion of the study entitled the effect of exchange rate and freight cost toward export volume of PT. Apparel One Indonesia 1 are as follows:

1. The result of the coefficient of determination is 0.445 , which means the export volume variable can be explained by the exchange rate and freight cost of $44.5 \%$. The remaining $55.5 \%$ is explained by other factors.

2. Exchange rate and freight cost together affect export volume of Adidas at PT Apparel One Indonesia 1 Semarang.

3. Exchange rate have a significant and negative effect toward export volume of Adidas at PT Apparel One Indonesia 1 Semarang.

4. Freight cost have a significant and negative effect toward export volume of Adidas at PT Apparel One Indonesia 1 Semarang. 
5. Variable exchange rate is a variable that dominantly affect export volume.

\section{Recommendation}

Based on this research, several recommendations are obtained in the form of suggestions to increase the export volume of Adidas at PT. Apparel One Indonesia 1, which are as follows:

1. For exchange rate, the depreciation of the rupiah will increase the volume of exports because price of products are cheaper at international price. PT. Apparel One Indonesia 1 should pay attention on exchange rate. It is better for the company to always observe the exchange rate fluctuations because export volume of PT Apparel One Indonesia 1 sensitives with exchange rate fluctuations. Anticipation is needed for Rupiah appreciation in future.

2. PT. Apparel One Indonesia 1 needs to pay attention to the number of freight costs incurred. Companies need to find cheap shipping price references among existing forwarding companies. The company can ask for a special price for the forwarding party because the company will make regular deliveries.

3. Furthermore, the company is advised to pay more attention to the timeliness in production activities. This is done so that distribution activities can be carried out maximally in one container shipment. If the shipment is done separately, or not as scheduled, the freight costs incurred will be even higher.

\section{REFERENCES}

Auliya, R. R., Setyadi, D., \& Rini, N. (2019). THE INFLUENCE OF SELLING PRICES AND EXCHANGE RATES ON BARECORE EXPORT VOLUME. JOBS (Jurnal Of Business Studies), 4(1), 7-18.

Barua, L., Zou, B., \& Zhou, Y. (2020). Machine learning for international freight transportation management: a comprehensive review. Research in Transportation Business \& Management, 100453.

Cardebat, J. M., \& Figuet, J. M. (2019). The impact of exchange rates on French wine exports. Journal of Wine Economics, 14(1), 71-89.

Chi, J. (2016). Exchange rate and transport cost sensitivities of bilateral freight flows between the US and China. Transportation Research Part A: Policy and Practice, 89, 1-13.

Colander, David C. 2011. MicroeconomicsSeven Edition. New York: McGrawHill Irwin

Edwards, L., \& Hlatshwayo, A. (2020). Exchange rates and firm export performance in South Africa (No. wp2020-1). World Institute for Development Economic Research (UNU-WIDER).

Ghozali, Imam. 2018. Aplikasi Analisis Multivariate dengan Program IBM

SPSS 25. Semarang, Badan Penerbit Universitas Diponegoro

Havenga, J. H., Witthöft, I. E., \& Simpson, Z. P. (2019). Macrologistics instrumentation: Integrated national freight flow and logistics cost measurement. Transport Policy.

Prasojo, Suryo Adi. 2017. Pengaruh Biaya Distribusi dan Harga Produk Terhadap Volume Penjualan Ekspor Pada Pupuk Organik SAN 500 gr (Studi Kasus Pada PT. Indmira Yogyakarta). Politeknik Negeri Semarang

Ratana, Achsani and Andati. 2012. Dampak Perubahan Nilai Tukar Mata Uang Terhadap Ekspor Indonesia. Bogor: Jurnal Manajemen \& Agribisnis, Vol.9 No.3, November 2012.

Rinaldy, Ikhlas dan Ardha Utama. 2018. Perdagangan Internasional Konsep\&Aplikasi. Jakarta: PT Bumi Aksara 
Sukirno,Sadono. 2014. Mikroekonomi Teori Pengantar. Jakarta: PT. Raja Grafindo Persada ---2010. Teori Pengantar Makroekonomi. Jakarta:PT Raja Grasindo Persada
Sugiyono. 2019. Statistika untuk Penelitian. Bandung: CV Alfabeta

Suseno, S.I. 2004. Sistem Kebijakan Nilai Tukar. Jakarta:Bank Indonesia. Bea Cukai 